\title{
Nationwide Drinking Water Sampling Campaign for Exposure Assessments in Denmark
}

\author{
Denitza Dimitrova Voutchkova ${ }^{1, *}$, Birgitte Hansen ${ }^{2}$, Vibeke Ernstsen ${ }^{3}$ \\ and Søren Munch Kristiansen 4 \\ 1 Department of Geography, National University of Singapore, 1 Arts Link, Kent Ridge, \\ Singapore 117570, Singapore \\ 2 Geological Survey of Denmark and Greenland (GEUS), 8000 Aarhus C, Denmark; bgh@geus.dk \\ 3 Geological Survey of Denmark and Greenland (GEUS), 1350 Copenhagen K, Denmark; ve@geus.dk \\ 4 Department of Geoscience, Aarhus University, 8000 Aarhus C, Denmark; smk@geo.au.dk \\ * Correspondence: geoddv@nus.edu.sg; Tel.: +65-6601-5991
}

Received: 11 January 2018; Accepted: 28 February 2018; Published: 7 March 2018

\begin{abstract}
Nationwide sampling campaign of treated drinking water of groundwater origin was designed and implemented in Denmark in 2013. The main purpose of the sampling was to obtain data on the spatial variation of iodine concentration and speciation in treated drinking water, which was supplied to the majority of the Danish population. This data was to be used in future exposure and epidemiologic studies. The water supply sector (83 companies, owning 144 waterworks throughout Denmark) was involved actively in the planning and implementation process, which reduced significantly the cost and duration of data collection. The dataset resulting from this collaboration covers not only iodine species $\left(\mathrm{I}^{-}, \mathrm{IO}_{3}{ }^{-}, \mathrm{TI}\right)$, but also major elements and parameters $(\mathrm{pH}$, electrical conductivity, DOC, TC, TN, $\mathrm{F}^{-}, \mathrm{Cl}^{-}, \mathrm{NO}_{3}{ }^{-}, \mathrm{SO}_{4}{ }^{2-}, \mathrm{Ca}^{2+}, \mathrm{Mg}^{2+}, \mathrm{K}^{+}, \mathrm{Na}^{+}$) and a long list of trace elements $(n=66)$. The water samples represent 144 waterworks abstracting about $45 \%$ of the annual Danish groundwater abstraction for drinking water purposes, which supply about 2.5 million Danes ( $45 \%$ of all Danish residents). This technical note presents the design, implementation, and limitations of such a sampling design in detail in order (1) to facilitate the future use of this dataset, (2) to inform future replication studies, or (3) to provide an example for other researchers.
\end{abstract}

Keywords: sampling design; drinking water supply; groundwater; inorganic composition; iodine; public health; exposure assessment

\section{Introduction}

The aim of this technical note is to provide a thorough account on the design of a nationwide drinking water sampling campaign implemented in Denmark in 2013. The main purpose of the sampling campaign was to inform about the spatial variation of iodine concentrations and speciation in Danish drinking water. Iodine is essential element that plays important role in the metabolism and early development of humans, but there was limited information on the local and regional variability of iodine species in Danish drinking water prior to our study [1]. Even though the main focus was on iodine, the resulting dataset can be used further for drinking water exposure assessments on other elements (e.g., lithium and strontium [2]) and following epidemiological studies (e.g., [3-5]). The methodology was briefly described in [1,2] with a focus on only few of the used analytes. In contrast, this technical note provides information on the entire dataset (major part of which has not been reported yet in peer-review publications). Here, we also elaborate on the design with specific focus on sampling site location choice and implementation limitations. The design details and the reasoning behind them may serve as a guide to others who are interested in conducting nationwide drinking water sampling for exposure studies or epidemiological analyses in Denmark 
and beyond. The existing drinking-water iodine studies rarely report selection criteria for drinking water sampling locations in satisfactory detail that limits the comparability between existing studies. The studies of Lv et al. [6] and Shen et al. [7] are exceptions with this respect, as there is enough detail for the water sampling to be reproducible and spatially representative. However, the highly cited studies on iodine in Danish drinking water preceding our sampling campaign lack this thoroughness: Pedersen et al. [8] took tap water samples from laboratories spread through Denmark $(n=55$, locations only shown on low resolution map); Andersen, Petersen, and Laurberg [9] collected samples from Danish waterworks $(n=22)$, choosing them to verify low and high drinking water iodine contents when compared with their previous study [8]; Rasmussen, Larsen, and Ovesen [10] collected tap water from what they denoted as "41 evenly distributed localities in the country" which were neither listed nor mapped. Another major drawback of these iodine-drinking water sampling campaigns was that they did not account for the specifics of Danish drinking-water supply system, which we have addressed in our work. Therefore, in this technical note, we first provide some background on Danish drinking water supply to set the scene, and then we elaborate on the design and implementation of this drinking water sampling campaign. The dataset resulting from our drinking water campaign has so far been used in several studies [1-5] (status March 2017). We foresee that the details provided in this technical note will facilitate the future use of this "historical" dataset and will inform potential replication studies in Denmark.

\section{Design}

\subsection{Drinking Water Supply in Denmark}

Denmark is relatively small country (about $43,000 \mathrm{~km}^{2}$ ), with about 5.6 million inhabitants. Danish drinking water supply relies entirely on groundwater. The present Danish landscape is shaped mainly since the Weichselian glaciation and most of the Danish primary and secondary aquifers consist of Quaternary or Miocene sand and gravel or Paleocene to Late Cretaceous chalk and limestone. The spatial variability of groundwater composition with focus on iodine is discussed further in $[11,12]$. Danish households rely greatly on the water supply system, bottled water consumption in 2013 was $22.8 \mathrm{~L} / \mathrm{cap}\left(0.127\right.$ million $\left.\mathrm{m}^{3}\right)$ [13], which was amongst the lowest in Europe and below the global average (30 L/cap [9]). Danish drinking water supply is characterized by decentralized structure of more than 2600 waterworks, with annual groundwater abstraction of about 400 million $\mathrm{m}^{3}$ per year [14], spread across the country. About $72 \%$ of the active waterworks have annual abstractions of $<0.1$ million $\mathrm{m}^{3}$, whereas about $3 \%$ are abstracting $>1$ million $\mathrm{m}^{3}$ [14]. Most of the Danish waterworks abstract groundwater from multiple wells or even multiple well sites. In some cases, groundwater from different aquifers is pumped up and mixed together before it gets to the treatment facilities. The raw groundwater undergoes simple physical and chemical treatment at the waterworks, consisting of aeration and sand filtration only. However, 74 waterworks (out of the $>2600$ ) with annual water production of about 50.47 million $\mathrm{m}^{3}$ have obtained permits to use some sort of advanced water treatment Table 1 [15]. Neither chlorination, nor ozone treatment are used, according to [15]. 
Table 1. Granted permits for advanced water treatment in Denmark (2007-2012). From those, number of active waterworks by 2012 and volumes of treated water produced yearly [15].

\begin{tabular}{ccccc}
\hline $\begin{array}{c}\text { Type of Permit for } \\
\text { Advanced Treatment }\end{array}$ & $\begin{array}{c}\text { Permits }(\boldsymbol{n}) \\
\text { 2007-2012 }\end{array}$ & $\begin{array}{c}\text { Active } \\
\text { Waterworks 2012 }\end{array}$ & $\begin{array}{c}\text { Treated Water } \\
\text { (million m } \mathbf{3}^{3} / \mathbf{y e a r} \text { ) }\end{array}$ & Examples of Treatment Methods \\
\hline Major components & 43 & 29 & 13.26 & $\begin{array}{l}\text { addition of sodium hydroxide, } \\
\text { precipitation by adding iron(II), } \\
\text { flocculation with polyaluminium chloride }\end{array}$ \\
\hline Inorganic trace elements & 36 & 31 & 3.67 & $\begin{array}{l}\text { addition of iron chloride, iron sulphate or } \\
\text { adsorption filters with iron oxide }\end{array}$ \\
\hline Organic micro-pollutants & 17 & 8 & 10.38 & activated carbon filters, intense stripping \\
\hline Microbiology & 22 & 6 & 23.32 & UV disinfection \\
\hline Total & 118 & 74 & $50.47^{1}$ & \\
\hline & 1 the numbers don't sum up precisely due to rounding.
\end{tabular}

\subsection{Sampling Site Selection}

There were few initial limitations of the sampling design in relation to the scale and the nature of the study. Sampling all of the active waterworks was cost-inefficient, thus the number of sampling points was initially limited to about 180 (based on budget limitations and labor-time). As the focus of the study was on the spatial variability of iodine in drinking water, the campaign consisted of a single sampling event. The snap-shot nature of this sampling campaign was partially overcome by studying the short term temporal variability at one of the large waterworks supplying Copenhagen area (8 samples for two week period) (see Supplementary Data accompanying [1]). The results were inconclusive; however, previous investigations have pointed to relatively stable conditions for iodine and lithium [1,5]. Studying the temporal variability was not in the scope of our study, so this dataset limitation should be kept in mind if/when the dataset is used by others. The stability of regulated water quality parameters in raw groundwater and treated drinking water can be further evaluated based on the mandatory data reports to Jupiter database (Iodine is not part of the regular quality checks). Jupiter is the Danish public nationwide geological and hydrological database, which is maintained by the Geological Survey of Denmark and Greenland (GEUS) (www.geus.dk/DK/data-maps/jupiter/) and serves as an integrated information system for geology, groundwater, and drinking water [16]. Details on the access to data in the Jupiter database from different users and on data flow to and from the database can be found in [16].

The sampling site selection was based on data extracted from the publicly available Jupiter database (maintained by Geological Survey of Denmark and Greenland, GEUS) on 6 December 2012, consisting of the postal addresses, geographic coordinates, and annual abstraction volumes of all public waterworks (either privately or publicly owned) each supplying more than nine households. Based on this data, about 397 million $\mathrm{m}^{3}$ groundwater abstraction volumes were reported for 2010 by 2585 waterworks supplying more than nine households. Two selection criteria were adopted (Figure 1):

1. the largest waterworks in each municipality polygon $(n=99)$, and

2. the largest one in each grid cell $(n=189,20 \times 20 \mathrm{~km})$ were selected.

The sampling campaign aimed to be representative for the drinking water (quality) supplied to as large proportion of the Danish population as possible. At the time of designing this campaign there was no readily available data on supplied area/population at the level of each waterworks, so the waterworks' size, based on groundwater abstraction volumes for 2010 , served as a proxy. The limited information on spatial variability of iodine in drinking water lead us to the second selection criteria, as to allow a geographically even coverage. When combining these two selection criteria, we identified 181 waterworks, from which only 27 had annual abstraction volumes $<0.2$ million $\mathrm{m}^{3}$. The 2010 groundwater abstraction volumes for none of the waterworks located in Sydjurs and Stevns municipalities were reported to Jupiter database, thus, 2007 data was used for these two municipalities instead. This added 5 more waterworks to the initial selection, resulting in a list with 
186 waterworks representing about $40 \%$ of the annual groundwater abstraction for drinking water purposes in Denmark. This coverage was considered acceptable for the purposes of our study, so we proceeded with contacting the companies owning these waterworks, so we could obtain sampling permissions and further information.

We incorporated feedback provided by some of the large water supply companies and adjusted the sampling site selection as to reflect the supply system complexity in some highly urbanized areas. Few companies advised us in inclusion of additional waterworks, as typically the supply of urbanized areas relies on more than one waterworks. Further corrections were needed also due to categorizing issues in the Jupiter data used for the initial selection: some of the ID numbers corresponded to single well sites (not the waterworks treatment facilities as usual), because some of the large waterworks report abstraction volumes for each well site separately to Jupiter. For these identified misclassification cases, the overlying waterworks (treatment facilities) were added to our selection list instead. After these adjustments, the final selection resulted in 189 sampling points all representing single waterworks, see Figure 1.

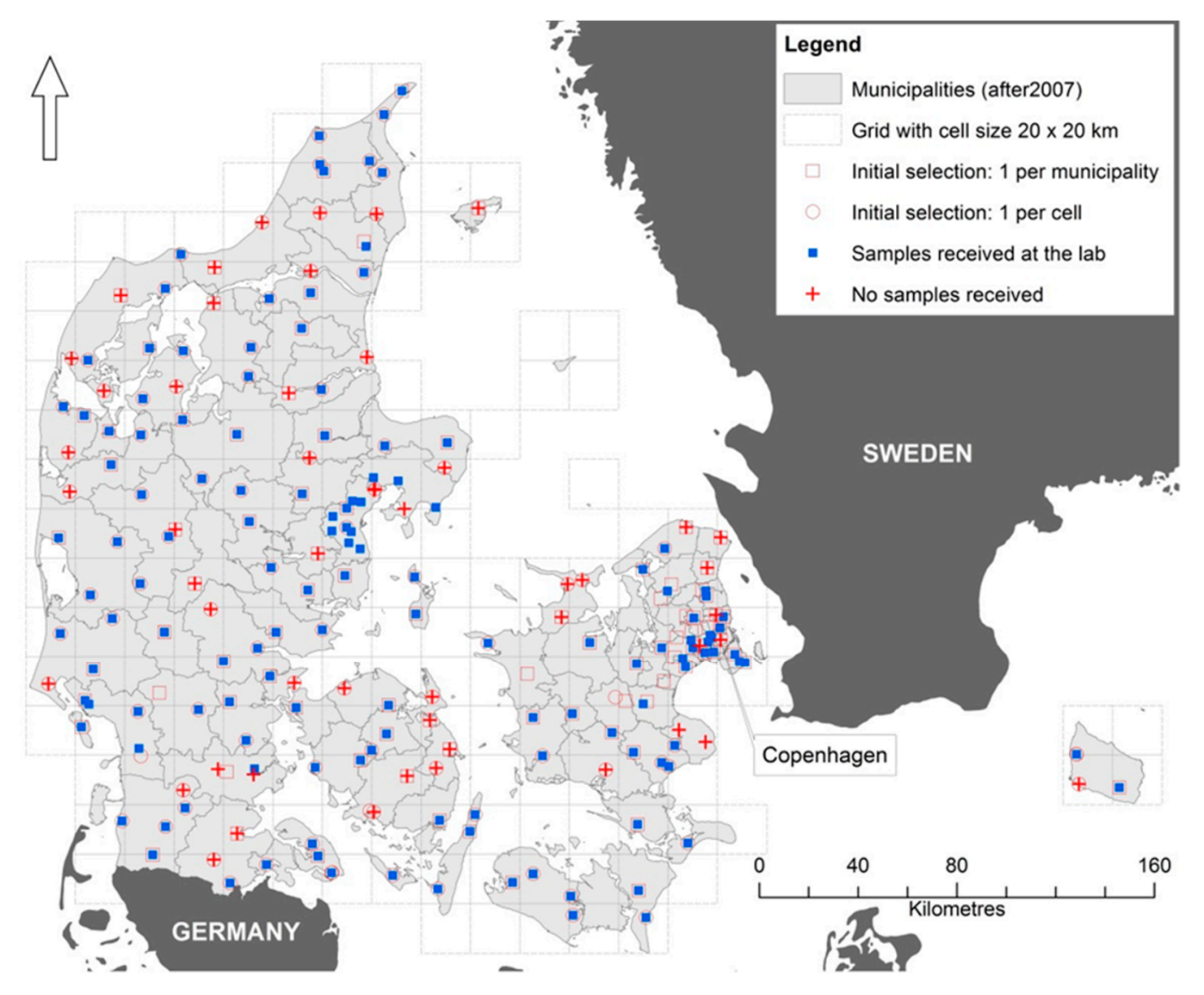

Figure 1. Sampling point location. Symbols: initial waterworks selection, based only on the two selection criteria ( $n=181$ ): 1st selection criteria (red empty square), 2nd criteria (red empty circle); waterworks which sent samples to the lab $(n=144)$ (blue square); contacted waterworks which did not participate i.e., no answer; negative answer; answered positively, but samples were not received at the lab (red cross) (note: the arrow indicates North direction).

\subsection{Sampling}

The sampling process was logistically challenging due to its spatial coverage. Since our study was aiming to obtain a snap-shot of the drinking water quality, prolonged sampling period was undesirable. After considering the practical challenges and estimating the time and resources needed, 
it was decided that a reasonable compromise is to involve the waterworks in the sampling process itself. Therefore, invitations for participations were sent to each identified owner of the selected waterworks. All who accepted our invitation received sampling materials, including the suit of sampling bottles and a manual describing the sampling procedure (Appendix A). We specified in the manual that the sampling point should be right after the treatment procedures and before the water leaves the facility to be supplied to consumers (at exit waterworks). Each sample consisted of four plastic bottles (i.e., centrifuge tubes, Figure A1) filled with treated drinking water. Field duplicates were planned randomly for $10 \%$ of the participating waterworks (duplicate sample consisted of eight bottles). Immediately after sampling the bottles were to be send to the Inorganic Lab at GEUS (Copenhagen, Denmark) by post. The samples were refrigerated at $4{ }^{\circ} \mathrm{C}$ degrees upon their arrival to the laboratory and were analyzed as soon as possible. To avoid overloading of the laboratory, the sampling packages were dispatched in two batches with two weeks difference in the beginning of April 2013. Despite this, most of the samples were received in the first four weeks of the period between 11 April and 12 June 2013 (Figure 2). A total of $76 \%$ of the samples were received at the lab the same day or a day after the sampling event (Figure 2).

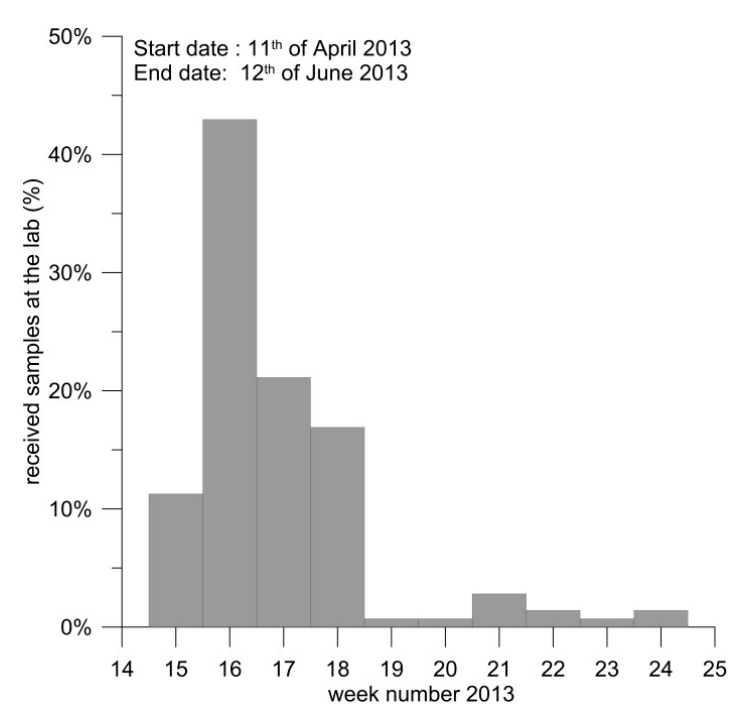

(a)

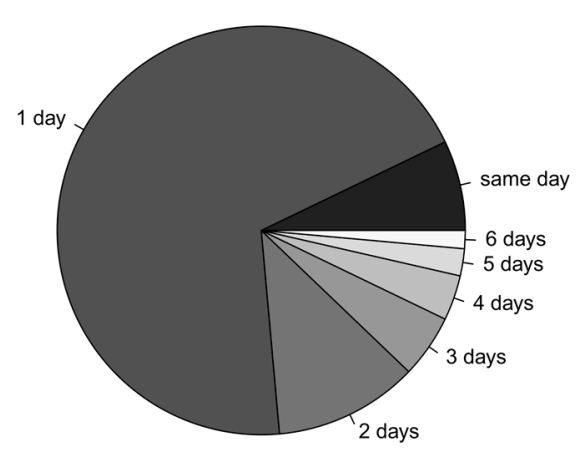

(b)

Figure 2. (a) Timing of samples received at the laboratory (\%) indicating that the largest part of the sampling was conducted between weeks 15 and 18 (week 14 in 2013 started on 1 April); (b) Shipping periods: proportion of samples received at the lab on the same day of sampling or 1-6 days later.

\subsection{Additional Data Collection}

Questionnaires with mixture of closed and open questions were also sent to the contact persons at the participating waterworks in regards to the groundwater extraction well sites, treatment procedures, and drinking water supply and export (Appendix B). Materials in any form or links with relevant online sources of reliable and updated information about the abstraction and supply areas were requested as well.

\section{Implementation}

\subsection{Water Sampling}

Positive answers for participation in this study were received for $80 \%$ of the selected waterworks $(n=152)$, while four waterworks $(2 \%)$ responded negatively. For the rest of the waterworks $(n=33,17.5 \%)$, there was no answer after follow-up e-mails and phone calls. Samples from 144 (95\% of the 152 which agreed to participate) were received and analyzed at the laboratory. Two of the 152 waterworks refused to 
receive the sampling packages and another sampling package was returned empty (open without the water samples). Taking into account the voluntary and non-profit character of the participation, the success-rate $(95 \%)$ is exceptionally high. The initial agreement for participation by one of the waterworks was changed after receiving the questionnaire (see Table A1). The explanation was that completing the questionnaire is too laborious (this case is included in the four that refused). It is suspected that the success rate of this campaign is also affected by the unreliable (not up-to-date, or wrong) contact information for some of the waterworks. Nevertheless, it is believed that higher success rate would most likely be achieved only if such sampling was part of a state monitoring regulated by law. Including the parameter of interest, i.e., here iodine, in the routine water-quality monitoring of the waterworks would be the optimal way of collecting data on nationwide scale which describes both the spatial and the temporal variation of water composition.

The spatial distribution of the drinking water dataset resulting of this sampling design is covering more or less evenly the entire country (Figure 1$)$. The dataset $(n=144)$ represents waterworks abstracting annually about 175 million $\mathrm{m}^{3}$, accounting for $45 \%$ of the total groundwater abstraction for drinking water purposes by all publicly and privately owned Danish waterworks $(n>2600)$. Only six of the waterworks can be considered small (annual abstraction $<0.1$ million $\mathrm{m}^{3}$ ), whereas $46(31.9 \%)$ have annual abstractions $>1$ million $\mathrm{m}^{3}$ [1]. Figure 2 of Supplementary data accompanying [1] provides more information on the abstraction volumes distribution from each of the 144 waterworks).

\subsection{Additional Data Collection}

The questionnaire was filled in at least partially for 94 waterworks (92 of which sent also water samples, $64 \%$ of total). Information about groundwater catchment areas of the production wells and well sites was provided in various formats. The varying quality of these data prevented their direct use for the purposes of the study; however, data on the geology at the waterworks' wells from Jupiter database (GEUS) was summarized for the needs of our data analyses [1].

The information on supply areas was provided by all 94 waterworks; however, the quality and the type of information also varied: written free description of aerial parts, hand drawn sketches, links to online GIS, reports with high resolution figures, digital geocoded data sources (e.g., AutoCad, MapInfo, AcrMap files). Geocoded digital data, which is considered the most reliable, was provided for only 28 of the waterworks. Until 2014, the information on supply areas of the waterworks was not present in asingle publicly-accessible database/repository, but instead it was part of the municipalities' strategy plans (in Danish "vandforsyningsplan"). However, Schullehner and Hansen [17] compiled a map with the water supply areas of 2852 waterworks covering the entire country by collecting and digitalizing data from various sources (incl. the digital geocoded data collected in this study). This map enables the spatial connection between water quality supplied by the Danish waterworks with the resident history, health, and economic-social status on a personal level for the entire Danish population (see example in [2]).

Based on this map [17] and two different datasets on residency, it was estimated that about $45.3 \%$ of all residents (by 2008) and $42.7 \%$ of all households (by 2012) are supplied with drinking water by the 144 waterworks included in this sampling campaign [2].

\section{Data and Data Accessibility}

The data on drinking water chemistry from the individual water works are not reported here as this is beyond the scope of this technical note. However, we include an overview of concentrations' level variation of major and minor elements (Figure 3), which may be of interest for future exposure, medical geology, or epidemiology studies. Methodological details for each of the analyzed parameters (including filtering, the analytical methods and detections limits) are provided in Appendix C.

Major elements and main parameters analyzed and included in the dataset $(n=13): \mathrm{pH}$, Electrical conductivity, Dissolved Organic Carbon, Total Carbon, Total Nitrogen, Fluoride, Chloride, Nitrate, Sulphate, Calcium, Magnesium, Potassium, and Sodium. 
Minor elements that were analyzed and included in the dataset $(n=69$, listed in alphabetic order): Aluminium, Antimony, Arsenic, Boron, Barium, Beryllium, Bismuth, Bromide, Cadmium, Cerium, Cobalt, Chromium, Caesium, Copper, Dysprosium, Erbium, Europium, Gallium, Gadolinium, Germanium, Gold, Hafnium, Holmium, Indium, Iron, Iridium, Iodide, Iodate, Iodine (total), Lanthanum, Lead, Lithium, Lutetium, Manganese, Mercury, Molybdenum, Niobium, Neodymium, Nickel, Osmium, Palladium, Phosphorus, Platinum, Praseodymium, Rhenium, Rhodium, Rubidium, Ruthenium, Samarium, Scandium, Selenium, Silicium, Silver, Strontium, Tantalum, Tellurium, Terbium, Thorium, Thallium, Thulium, Tin, Titanium, Tungsten, Uranium, Vanadium, Yttrium, Ytterbium, Zink, and Zircon.

The dataset obtained as part of this sampling campaign is partially available through the Danish open-access database Jupiter (GEUS). In general, all Jupiter data can be searched, mapped, visualized, and downloaded free of charge. The chemical analyses are associated with specific sample number, geographic location (via the waterworks identification number "JUPITER ID"), indication for the type of analyzed water (raw, treated, etc.), and specific sampling point. The data obtained as part of this study has been assigned unique attribute "JODGCP" (under project code). Due to the specifics of the individual agreements with some of the water supply companies involved in the sampling, however, the results from the 2013 sampling campaign will not be made readily available for download by "unprivileged users" (access classification, according to Figure 1A of [16]).

\section{Concentrations $(\mathrm{mg} / \mathrm{l})$}

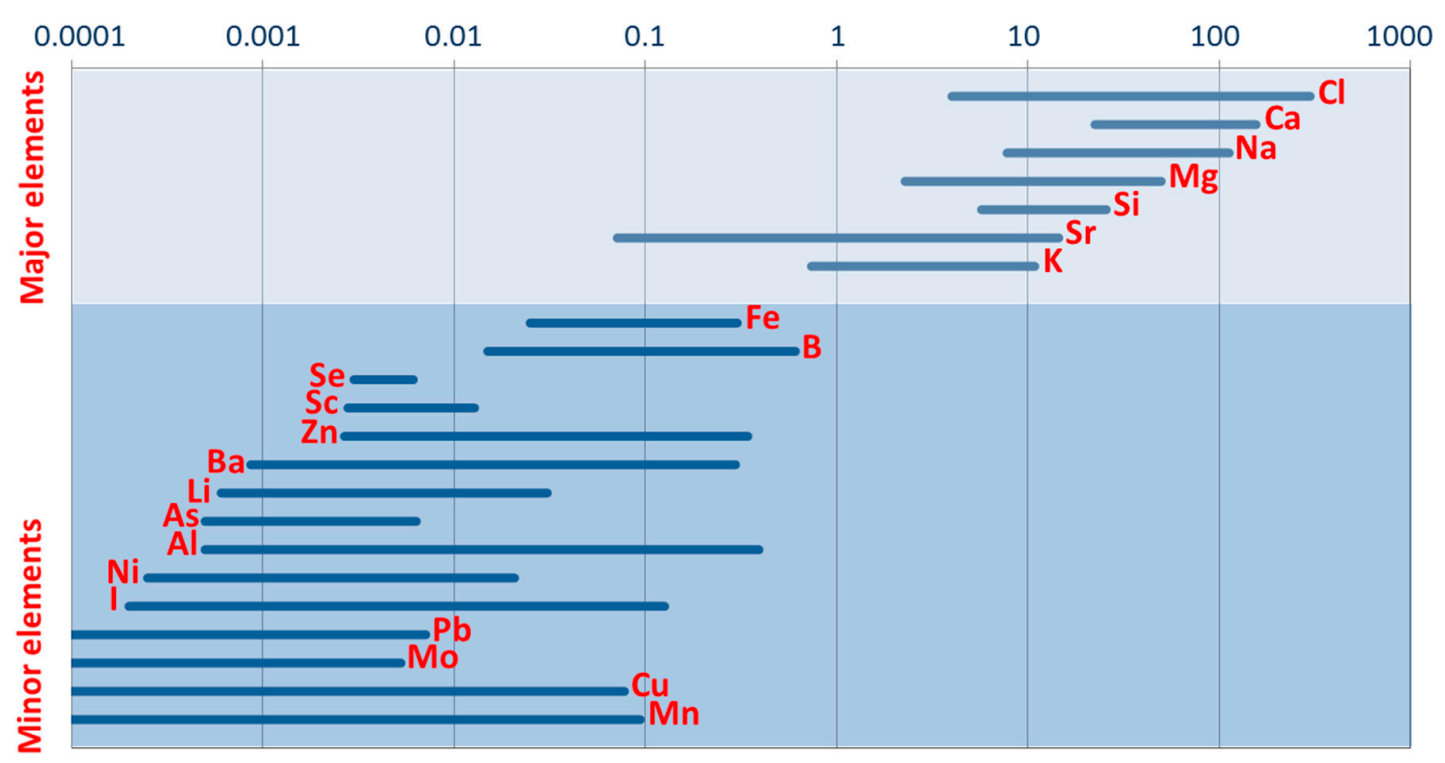

Figure 3. Concentration ranges for selected major and minor elements in drinking water from the 2013 sampling campaign of 144 major Danish waterworks revealing large concentration variability.

\section{Conclusions}

Drinking water quality monitoring is a mandatory part of EU countries' legislation, as stipulated in the EU drinking water directive (Council Directive 98/83/EC of 3 November 1998 on the quality of water intended for human consumption). The Directive's objective is to protect human health from the adverse effects of drinking water contamination. However, monitoring is only focusing on compounds with well-documented adverse effects, while the parameters with long-term adverse effects or naturally occurring elements with likely positive effects on human health are omitted. To study public health effects from such non-mandatory compounds, specific sampling campaigns are needed, and detailed account on their design and implementation is necessary to ensure the integrity and future reuse of the data. This technical note presents such an example of a successful involvement of the drinking 
water supply sector in a university research project focusing on iodine speciation in drinking water, but also including in total 82 elements and parameters for 144 waterworks in Denmark. The success rate and the spatial cover of the obtained drinking water chemistry data are surprisingly high taking into account the limitations of the methodology. The quality and quantity of the obtained data was considered appropriate with respect to the formulated goals of our studies [1,2]. However, for future use of this dataset, it is recommended to carefully consider its appropriateness with respect to the specific study goals. It should be kept in mind that this dataset represents a single sampling event and it is focused on spatial rather than temporal variability. Further, the chosen sampling methodology may have posed some problems with the reliability of some of the other hydrogeochemical data, especially with the volatile and redox sensitive elements. Naturally, treated Danish drinking water has low content of dissolved organic matter, so for the purposes of our study, sample preservation immediately after sampling was not needed. However, complexation may have affected samples with higher organic matter levels.

Acknowledgments: The sampling campaign was organized as part of a GEOCENTER research project "Iodine in the hydrological cycle of Denmark: implications for human health", financed by Aarhus University (AU) and the Geological Survey of Denmark and Greenland (GEUS). The 83 water supply companies who own the waterworks participating in this sampling campaign are gratefully acknowledged for their involvement. Acknowledgements are due also to Brian L. Sørensen, Kim H. Esbensen, Christina R. Lynge, Pernille Stockmarr, Jørgen Kystol, Lucia M. M. Petersen for their invaluable participation in this project.

Author Contributions: Birgitte Hansen, Søren Munch Kristiansen and Vibeke Ernstsen obtained funding for this project. All co-authors participated in the design; Vibeke Ernstsen was responsible for the laboratory analyses; Denitza Dimitrova Voutchkova prepared the sampling materials and analyzed all collected data; Denitza Dimitrova Voutchkova wrote the first draft of this technical note. All co-authors contributed equally in revising multiple versions of this technical note.

Conflicts of Interest: The authors declare no conflict of interest. 


\section{Appendix A}

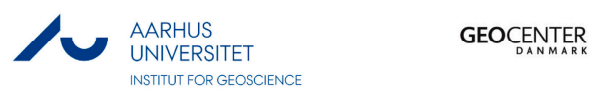

\section{Vejledning i prøveudtagning}

til forskningsprojekt om jod i drikkevand

Det er vigtigt, at vandprøverne udtages ved afgangen af vandværket efter

al vandbehandling dvs. også efter eventuel UV-og ozon-behandling.

Udtag vandprøver og send dem inden den 30. april 2013.

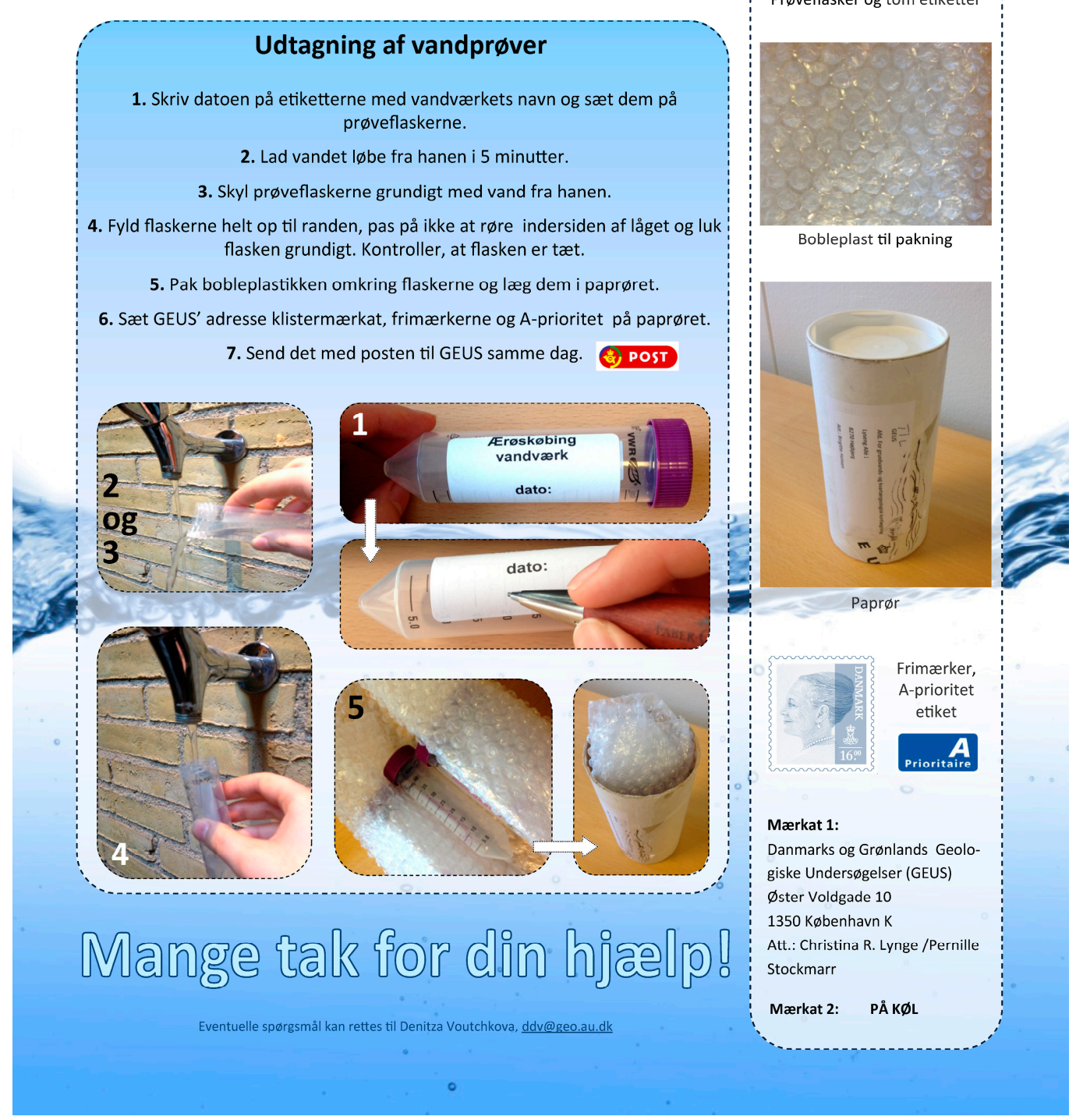

Figure A1. Manual for drinking water sampling sent to the participating waterworks (in Danish only); for translation see Box A1. 
Box A1. Translation of the sampling manual from Danish (Figure A1).

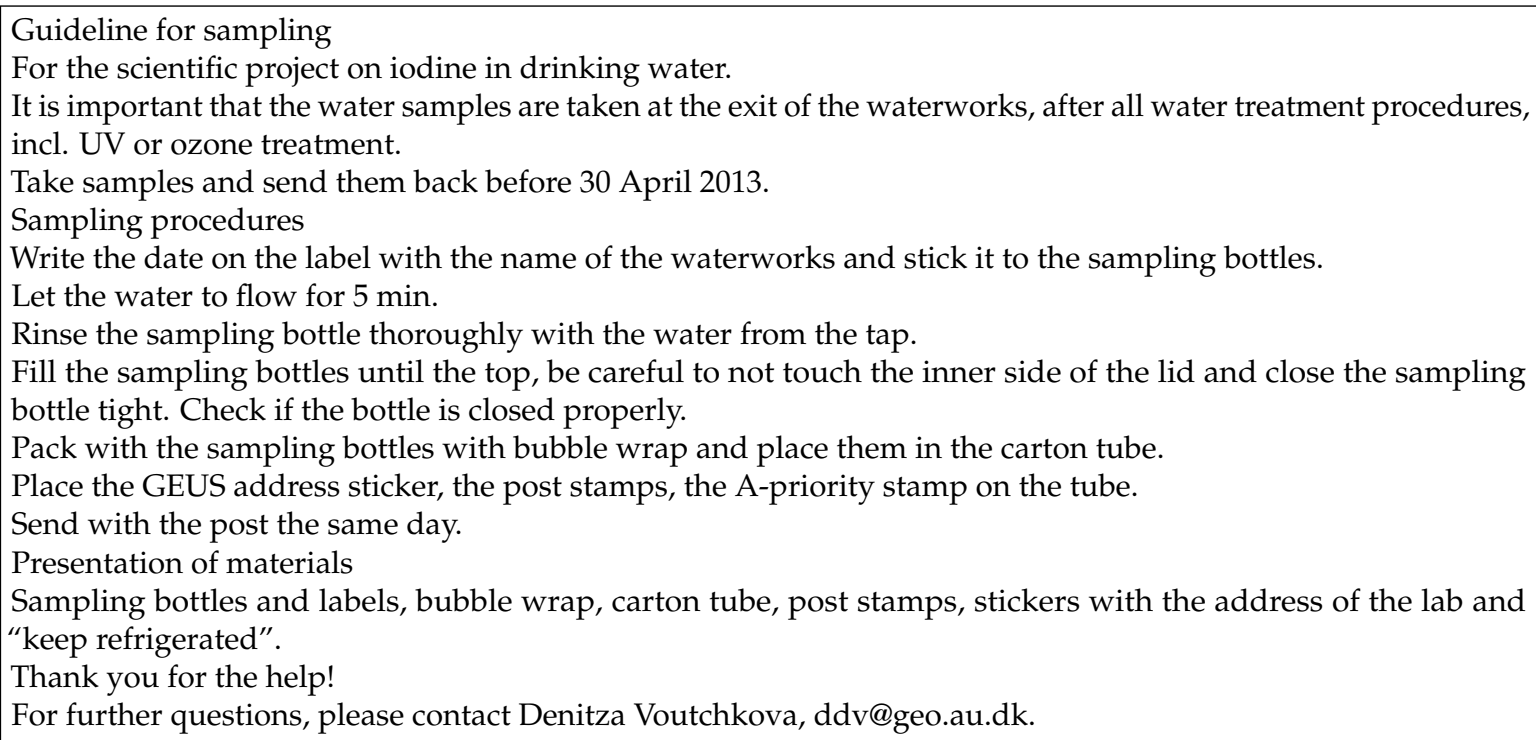

\section{Appendix B}

Table A1. Questionnaire (in Danish and translated in English).

\begin{tabular}{|c|c|}
\hline Danish Text (Original) & English Translation \\
\hline $\begin{array}{l}\text { Indsamling af vandprøver til forskningsprojekt om jod i } \\
\text { drikkevand }\end{array}$ & $\begin{array}{l}\text { National sampling campaign for the research project on } \\
\text { iodine in drinking water }\end{array}$ \\
\hline Dette spørgeskema skal bruges i forskningsprojektet “Jod & This questionnaire will be used in the research project \\
\hline i det hydrologiske kredsløb i Danmark: betydning for & "Iodine in the hydrological cycle in Denmark: implications \\
\hline mellem GEUS og Institut for Geoscience, Aarhus & and the Department of Geoscience, Aarhus University, and \\
\hline Universitet, og vi håber I kan besvare så mange af vore & we hope you could answer as many of the questions as \\
\hline spørgsmål som muligt. Formålet med projektet er, at & possible. The purpose of the project is to obtain new \\
\hline opnå ny videnskabelig forståelse af hvordan jod fordeler & scientific understanding of how iodine is distributed in \\
\hline sig i dansk grund- og drikkevand samt belyse gavnlige & Danish groundwater and drinking water, as well as to \\
\hline effekter af jod i drikkevandet i forhold til folkesundheden. & elucidate the beneficial effect of iodine in drinking water in \\
\hline I alt 180 vandforsyninger fordelt over hele landet & to public health. A total of 180 waterworks across \\
\hline $\begin{array}{l}\text { kontaktes og anmodes om at levere vandprøver til } \\
\text { forskningsprojektet. }\end{array}$ & $\begin{array}{l}\text { the country were contacted and asked to collect samples } \\
\text { for this research project. }\end{array}$ \\
\hline $\begin{array}{l}\text { For at opnå forståelse for jod og drikkevand, har vi brug } \\
\text { for oplysninger om vandværket som vandprøven }\end{array}$ & $\begin{array}{l}\text { In order to better understand the iodine variation in } \\
\text { drinking water, we need additional information on the }\end{array}$ \\
\hline kommer fra. En del af de oplysninger vi beder om & waterworks from which the samples come from. Some of \\
\hline herunder er tilgængelige i GEUS' Jupiter-database, men & the information we request below might be available in the \\
\hline denne er desværre ikke opdateret med hvordan jeres & Jupiter database, but might not be up-to date. As the \\
\hline vandværk fungerer når prøven udtages. Da resultaterne & results are going to be used in a research project, it is very \\
\hline skal anvendes i et forskningsprojekt er det meget vigtigt, & important that we have the current and accurate \\
\hline at vi har opdaterede og korrekte oplysninger. Så vi håber & information. So, we hope that you understand why we are \\
\hline $\begin{array}{l}\text { derfor, I har forståelse for, at vi beder om disse } \\
\text { oplysninger som ellers synes offentligt tilgængelige. }\end{array}$ & $\begin{array}{l}\text { asking for this information which is anyway publicly } \\
\text { available. }\end{array}$ \\
\hline Udfyld venligst spørgeskemaet og send den til Denitza & Please complete the questionnaire and send it to Denitza \\
\hline Voutchkova ddv@geo.au.dk senest XX Juni 2013. & Voutchkova ddv@geo.au.dk the latest XX June 2013. \\
\hline Original Questions: & Translated Questions: \\
\hline 1 Vandværkets navn: & Name of the waterwork \\
\hline
\end{tabular}


Table A1. Cont.

\begin{tabular}{|c|c|c|}
\hline & Danish Text (Original) & English Translation \\
\hline 2 & $\begin{array}{l}\text { Vandværkets adresse (UTM koordinater eller adresse } \\
\text { inklusiv postnummer: } \\
\text { X: } \\
\text { Y: } \\
\text { Address: }\end{array}$ & $\begin{array}{l}\text { Address of the waterworks (UTM coordinates or } \\
\text { address incl. post number): } \\
\text { X: } \\
\text { Y: } \\
\text { Address: }\end{array}$ \\
\hline 3 & Identifikations nummer (JUPITER/EAN): & Identification number (JUPITER/EAN) \\
\hline 4 & $\begin{array}{l}\text { Vandværkets behandlingsmetoder (ja/nej): } \\
\text { (a) Kun iltning: } \\
\text { (b) Iltning + filtrering: } \\
\text { (c) UV eller ozonering: } \\
\text { (d) andre metoder: } \\
\text { hvis (b) specificer filtertypen: Åben/Lukket } \\
\text { hvis (d) specificer metoder: }\end{array}$ & $\begin{array}{l}\text { Treatment procedures in the waterworks (yes/no): } \\
\text { (a) Only aeration: } \\
\text { (b) Aeration + filtration: } \\
\text { (c) UV or ozonation: } \\
\text { (d) more sophisticated treatment: } \\
\text { if (b) specify what type of filter: Open/Closed } \\
\text { if (d) specify what type it is: }\end{array}$ \\
\hline 5 & $\begin{array}{l}\text { Har I for nylig ændret behandlingsmetoderne? } \\
\text { (a) Ja } \\
\text { (b) Nej } \\
\text { hvis (a) Specificer hvornår: } \\
\text { hvis (b) Hvilket år blev metoderne iværksat: }\end{array}$ & $\begin{array}{l}\text { Have you changed the treatment recently? } \\
\text { (a) Yes } \\
\text { (b) No } \\
\text { If (a) specify when: } \\
\text { If (b) which year was implemented: }\end{array}$ \\
\hline 6 & $\begin{array}{l}\text { Har I ét eller flere rentvandstanke? } \\
\text { (a) Ja } \\
\text { (b) Nej } \\
\text { hvis (a) Hvilket volumen har tanken/tankene (ca). }\end{array}$ & $\begin{array}{l}\text { Is/are there a pure water tank/s? } \\
\text { (a) Yes } \\
\text { (b) No }\end{array}$ \\
\hline 7 & $\begin{array}{l}\text { Fra hvor mange kildepladser indvinder I vand til dette } \\
\text { vandværk? }\end{array}$ & How many well sites do you abstract water from? \\
\hline 8 & $\begin{array}{l}\text { Vil I venligst medsende information om } \\
\text { indvindingsboringer og/eller-oplandsområder. } \\
\text { (markere med et kryds hvilken/hvilke filtyper, der er tale } \\
\text { om): } \\
\text { (a) Indtegnet på kort: } \\
\text { (b) Shape file: } \\
\text { (c) AutoCAD file: } \\
\text { (d) Vandforsyningsplan eller rapport: } \\
\text { (e) Link til online information: }\end{array}$ & $\begin{array}{l}\text { Could you please attach information about the } \\
\text { abstraction wells and/or the groundwater catchment } \\
\text { areas (mark with a cross what kind of file are you } \\
\text { providing): } \\
\text { (a) Drawn on a map } \\
\text { (b) Shape file } \\
\text { (c) AutoCAD file } \\
\text { (d) Waterworks strategy plans or reports: } \\
\text { (e) Link to online information }\end{array}$ \\
\hline 9 & $\begin{array}{l}\text { Hvor meget drikkevand produceredes (ca.): } \\
\text { i 2010: } \\
\text { i 2011: }\end{array}$ & $\begin{array}{l}\text { How much drinking water was produced (ca.): } \\
\text { In 2010: } \\
\text { In 2011: }\end{array}$ \\
\hline 10 & $\begin{array}{l}\text { Hvor meget af det produceredes vand (\%) forsyner (ca.): } \\
\text { (a) Forbrugere: } \\
\text { (b) Industri: } \\
\text { (c) Andet: } \\
\text { hvis (b) Specificer hvilken slags industri der især er tale om: } \\
\text { hvis (c) Specificer det "andet" som der især er tale om: }\end{array}$ & $\begin{array}{l}\text { How much of the produced water (\%) is supplied to the: } \\
\text { (a) Consumers: } \\
\text { (b) Industries: } \\
\text { (c) Other: } \\
\text { if (b) specify what kind of industry: } \\
\text { if (c) specify what kind of other customer: }\end{array}$ \\
\hline 11 & $\begin{array}{l}\text { Vil I venligst sende os information om forsyningsområdet } \\
\text { (hvilke byer eller områder) der normalt forsynes med vand } \\
\text { fra vandværket. (markere med et kryds hvilken/hvilke } \\
\text { filtyper, der er tale om): } \\
\text { (a) Indtegnet på kort: } \\
\text { (b) Shape file: } \\
\text { (c) Autocad file: } \\
\text { (d) Vandforsyningsplan eller rapport: } \\
\text { (e) Link til online information: }\end{array}$ & $\begin{array}{l}\text { Could you please attach information about which } \\
\text { city/village or parts of the city are supplied by the } \\
\text { waterworks normally. (mark with a cross what kind } \\
\text { of file are you providing): } \\
\text { (a) Drawn on a map } \\
\text { (b) Shape file } \\
\text { (c) Autocad file } \\
\text { (d) Waterwork strategy plans or reports: } \\
\text { (e) Link to online information }\end{array}$ \\
\hline
\end{tabular}


Table A1. Cont.

\begin{tabular}{|c|c|c|}
\hline & Danish Text (Original) & English Translation \\
\hline \multirow{6}{*}{12} & Importerer eller eksporterer I drikkevand? & Do you import or export drinking water? \\
\hline & (a) Ja, vi importerer og eksporterer & (a) Yes, we import and export \\
\hline & (b) Ja, vi importerer & (b) Yes, we import \\
\hline & (c) Ja, vi eksporterer & (c) Yes, we export \\
\hline & (d) $\mathrm{Nej}$ & (d) No \\
\hline & $\begin{array}{l}\text { Hvis (a), (b), (c) specificer: } \\
\text { hvorfra og hvor mange } \mathrm{m}^{3} \text { (2010 og 2011): } \\
\text { Hvortil og hvor mange } \mathrm{m}^{3} \text { (2010 og 2011): }\end{array}$ & $\begin{array}{l}\text { If (a), (b), (c), specify: } \\
\text { from where and how much ( } 2010 \text { and 2011): } \\
\text { to where and how much ( } 2010 \text { and 2011): }\end{array}$ \\
\hline \multirow{4}{*}{13} & $\begin{array}{l}\text { Dette spørgeskema er udfyldt af: } \\
\text { Navn: }\end{array}$ & $\begin{array}{l}\text { This questionnaire was filled in by: } \\
\text { Name: }\end{array}$ \\
\hline & Dato: & Date: \\
\hline & E-mail: & e-mail: \\
\hline & Telefonnummer: & Phone number: \\
\hline \multirow{3}{*}{14} & $\begin{array}{l}\text { Ønsker I at modtage analyseresultaterne når alle analyser } \\
\text { er færdige om ca. } 1 \text { år? }\end{array}$ & $\begin{array}{l}\text { Would you like to receive the results when they are } \\
\text { ready (in about } 1 \text { year)? }\end{array}$ \\
\hline & (a) Yes & (a) Yes \\
\hline & (b) No & (b) No \\
\hline \multirow[t]{2}{*}{15} & Andre kommentarer: & Other comments: \\
\hline & Danish Text (Original) & English Translation \\
\hline \multicolumn{2}{|r|}{$\begin{array}{l}\text { Mange tak for hjælpen! } \\
\text { Hvis der er spørgsmål kontakt Ph.D. studerende Denitza } \\
\text { Voutchkova ddv@geo.au.dk. } \\
\text { Spørgsmål kan også rettes til lektor Søren M. Kristiansen, } \\
\text { Institut for Geoscience på tlf. XXXX eller til seniorforsker } \\
\text { Birgitte Hansen, GEUS, på tlf. XXXX. }\end{array}$} & $\begin{array}{l}\text { Thank you very much for the assistance! } \\
\text { If you have any questions, please contact Ph.D. } \\
\text { student Denitza Voutchkova ddv@geo.au.dk. } \\
\text { Questions may also be addressed to Associate } \\
\text { Professor Søren M. Kristiansen, Department of } \\
\text { Geoscience, phone: XXX, or to Senior researcher } \\
\text { Birgitte Hansen, GEUS, phone number: XXX. }\end{array}$ \\
\hline
\end{tabular}




\section{Appendix C}

Table A2. Methodological details for all analyzed parameters and chemical elements.

\begin{tabular}{|c|c|c|c|c|c|}
\hline Parameter or Element & Chemical Formula & Analytical Method & Filtering & Unit & Detection Limit \\
\hline $\mathrm{pH}$ & $\mathrm{pH}$ & $\mathrm{pH}$ meter & no & $\mathrm{pH}$ & \\
\hline Electrical conductivity & EC & Conductivity meter & no & $\mu \mathrm{S} / \mathrm{cm}$ & \\
\hline Iodide & $\mathrm{I}^{-}$ & IC & Filtered 0.45 PES & $\mathrm{I} \mu \mathrm{g} / \mathrm{L}$ & 0.9 \\
\hline Iodate & $\mathrm{IO}_{3}^{-}$ & IC & Filtered 0.45 PES & $\mathrm{IO}_{3} \mu \mathrm{g} / \mathrm{L}$ & 1.4 \\
\hline Iodine & $\mathrm{I}$ & ICP-MS & Filtered 0.45 PES & $\mathrm{I} \mu \mathrm{g} / \mathrm{L}$ & 0.2 \\
\hline Dissolved organic carbon & DOC & Total Organic Carbon Analyzer, Catalytic oxidation/NDIR method & Filtered 0.45 PES & $\mathrm{C} \mathrm{mg} / \mathrm{L}$ & 0.5 \\
\hline Total inorganic carbon & TIC & Total Organic Carbon Analyzer, Catalytic oxidation/NDIR method & Filtered 0.45 PES & $\mathrm{Cmg} / \mathrm{L}$ & 0.5 \\
\hline Total nitrogen & $\mathrm{TN}$ & Total Organic Carbon Analyzer/Chemiluminescence & Filtered 0.45 PES & $\mathrm{N} \mathrm{mg/L}$ & 0.25 \\
\hline Fluoride & $\mathrm{F}^{-}$ & IC & Filtered 0.45 PES & $\mathrm{mg} / \mathrm{L}$ & 0.03 \\
\hline Chloride & $\mathrm{Cl}^{-}$ & IC & Filtered 0.45 PES & $\mathrm{mg} / \mathrm{L}$ & 0.01 \\
\hline Bromide & $\mathrm{Br}^{-}$ & IC & Filtered 0.45 PES & $\mathrm{mg} / \mathrm{L}$ & 0.02 \\
\hline Nitrate & $\mathrm{NO}_{3}^{-}$ & IC & Filtered 0.45 PES & $\mathrm{mg} / \mathrm{L}$ & 0.03 \\
\hline Sulfate & $\mathrm{SO}_{4}^{--}$ & IC & Filtered 0.45 PES & $\mathrm{mg} / \mathrm{L}$ & 0.03 \\
\hline Calcium & $\mathrm{Ca}^{++}$ & IC & Filtered 0.45 PES & $\mathrm{mg} / \mathrm{L}$ & 0.06 \\
\hline Potassium & $\mathrm{K}^{+}$ & IC & Filtered 0.45 PES & $\mathrm{mg} / \mathrm{L}$ & 0.04 \\
\hline Sodium & $\mathrm{Na}^{+}$ & IC & Filtered 0.45 PES & $\mathrm{mg} / \mathrm{L}$ & 0.03 \\
\hline Magnesium & $\mathrm{Mg}^{++}$ & IC & Filtered 0.45 PES & $\mathrm{mg} / \mathrm{L}$ & 0.04 \\
\hline Silver & Ag & ICP-MS & Filtered 0.45 PES & $\mathrm{mg} / \mathrm{L}$ & 0.005 \\
\hline Aluminium & $\mathrm{Al}$ & ICP-MS & Filtered 0.45 PES & $\mathrm{mg} / \mathrm{L}$ & 0.1 \\
\hline Arsenic & As & ICP-MS & Filtered 0.45 PES & $\mathrm{mg} / \mathrm{L}$ & 0.01 \\
\hline Gold & $\mathrm{Au}$ & ICP-MS & Filtered 0.45 PES & $\mathrm{mg} / \mathrm{L}$ & 0.001 \\
\hline Boron & B & ICP-MS & Filtered 0.45 PES & $\mathrm{mg} / \mathrm{L}$ & 0.5 \\
\hline Barium & Ва & ICP-MS & Filtered 0.45 PES & $\mathrm{mg} / \mathrm{L}$ & 0.005 \\
\hline Berillium & $\mathrm{Be}$ & ICP-MS & Filtered 0.45 PES & $\mathrm{mg} / \mathrm{L}$ & 0.01 \\
\hline Bismuth & $\mathrm{Bi}$ & ICP-MS & Filtered 0.45 PES & $\mathrm{mg} / \mathrm{L}$ & 0.005 \\
\hline Calcium & $\mathrm{Ca}$ & ICP-MS & Filtered 0.45 PES & $\mathrm{mg} / \mathrm{L}$ & 0.5 \\
\hline Cadmium & $\mathrm{Cd}$ & ICP-MS & Filtered 0.45 PES & $\mathrm{mg} / \mathrm{L}$ & 0.001 \\
\hline Cerium & $\mathrm{Ce}$ & ICP-MS & Filtered 0.45 PES & $\mathrm{mg} / \mathrm{L}$ & 0.001 \\
\hline Chloride & $\mathrm{Cl}$ & ICP-MS & Filtered 0.45 PES & $\mathrm{mg} / \mathrm{L}$ & 50 \\
\hline Cobalt & Co & ICP-MS & Filtered 0.45 PES & $\mathrm{mg} / \mathrm{L}$ & 0.001 \\
\hline Chromium & $\mathrm{Cr}$ & ICP-MS & Filtered 0.45 PES & $\mathrm{mg} / \mathrm{L}$ & 0.05 \\
\hline Casium & Cs & ICP-MS & Filtered 0.45 PES & $\mathrm{mg} / \mathrm{L}$ & 0.001 \\
\hline Copper & $\mathrm{Cu}$ & ICP-MS & Filtered 0.45 PES & $\mathrm{mg} / \mathrm{L}$ & 0.001 \\
\hline Dysprosium & Dy & ICP-MS & Filtered 0.45 PES & $\mathrm{mg} / \mathrm{L}$ & 0.001 \\
\hline Erbium & Er & ICP-MS & Filtered 0.45 PES & $\mathrm{mg} / \mathrm{L}$ & 0.001 \\
\hline Europium & $\mathrm{Eu}$ & ICP-MS & Filtered 0.45 PES & $\mathrm{mg} / \mathrm{L}$ & 0.001 \\
\hline Iron & $\mathrm{Fe}$ & ICP-MS & Filtered 0.45 PES & $\mathrm{mg} / \mathrm{L}$ & 5 \\
\hline Gallium & $\mathrm{Ga}$ & ICP-MS & Filtered 0.45 PES & $\mathrm{mg} / \mathrm{L}$ & 0.001 \\
\hline Gadolinium & $\mathrm{Gd}$ & ICP-MS & Filtered 0.45 PES & $\mathrm{mg} / \mathrm{L}$ & 0.001 \\
\hline Germanium & Ge & ICP-MS & Filtered 0.45 PES & $\mathrm{mg} / \mathrm{L}$ & 0.001 \\
\hline Hafnium & $\mathrm{Hf}$ & ICP-MS & Filtered 0.45 PES & $\mathrm{mg} / \mathrm{L}$ & 0.001 \\
\hline Mercury & $\mathrm{Hg}$ & ICP-MS & Filtered 0.45 PES & $\mathrm{mg} / \mathrm{L}$ & 0.001 \\
\hline
\end{tabular}


Table A2. Cont.

\begin{tabular}{|c|c|c|c|c|c|}
\hline Parameter or Element & Chemical Formula & Analytical Method & Filtering & Unit & Detection Limit \\
\hline Holmium & Ho & ICP-MS & Filtered 0.45 PES & $\mathrm{mg} / \mathrm{L}$ & 0.001 \\
\hline Indium & In & ICP-MS & Filtered 0.45 PES & $\mathrm{mg} / \mathrm{L}$ & 0.001 \\
\hline Iridium & $\mathrm{Ir}$ & ICP-MS & Filtered 0.45 PES & $\mathrm{mg} / \mathrm{L}$ & 0.001 \\
\hline Potassium & $\mathrm{K}$ & ICP-MS & Filtered 0.45 PES & $\mathrm{mg} / \mathrm{L}$ & 2 \\
\hline Lanthanum & $\mathrm{La}$ & ICP-MS & Filtered 0.45 PES & $\mathrm{mg} / \mathrm{L}$ & 0.001 \\
\hline Lithium & $\mathrm{Li}$ & ICP-MS & Filtered 0.45 PES & $\mathrm{mg} / \mathrm{L}$ & 0.005 \\
\hline Lutetium & $\mathrm{Lu}$ & ICP-MS & Filtered 0.45 PES & $\mathrm{mg} / \mathrm{L}$ & 0.001 \\
\hline Magnesium & $\mathrm{Mg}$ & ICP-MS & Filtered 0.45 PES & $\mathrm{mg} / \mathrm{L}$ & 0.05 \\
\hline Manganese & $\mathrm{Mn}$ & ICP-MS & Filtered 0.45 PES & $\mathrm{mg} / \mathrm{L}$ & 0.005 \\
\hline Molybdenum & Mo & ICP-MS & Filtered 0.45 PES & $\mathrm{mg} / \mathrm{L}$ & 0.005 \\
\hline Sodium & $\mathrm{Na}$ & ICP-MS & Filtered 0.45 PES & $\mathrm{mg} / \mathrm{L}$ & 0.1 \\
\hline Niobium & $\mathrm{Nb}$ & ICP-MS & Filtered 0.45 PES & $\mathrm{mg} / \mathrm{L}$ & 0.001 \\
\hline Neodymium & $\mathrm{Nd}$ & ICP-MS & Filtered 0.45 PES & $\mathrm{mg} / \mathrm{L}$ & 0.001 \\
\hline Nickel & $\mathrm{Ni}$ & ICP-MS & Filtered 0.45 PES & $\mathrm{mg} / \mathrm{L}$ & 0.01 \\
\hline Osmium & Os & ICP-MS & Filtered 0.45 PES & $\mathrm{mg} / \mathrm{L}$ & 0.001 \\
\hline Phosphorus & $\mathrm{P}$ & ICP-MS & Filtered 0.45 PES & $\mathrm{mg} / \mathrm{L}$ & 2 \\
\hline Lead & $\mathrm{Pb}$ & ICP-MS & Filtered 0.45 PES & $\mathrm{mg} / \mathrm{L}$ & 0.005 \\
\hline Palladium & $\mathrm{Pd}$ & ICP-MS & Filtered 0.45 PES & $\mathrm{mg} / \mathrm{L}$ & 0.001 \\
\hline Praseodymium & $\operatorname{Pr}$ & ICP-MS & Filtered 0.45 PES & $\mathrm{mg} / \mathrm{L}$ & 0.001 \\
\hline Platinum & $\mathrm{Pt}$ & ICP-MS & Filtered 0.45 PES & $\mathrm{mg} / \mathrm{L}$ & 0.001 \\
\hline Rubidium & $\mathrm{Rb}$ & ICP-MS & Filtered 0.45 PES & $\mathrm{mg} / \mathrm{L}$ & 0.001 \\
\hline Rhenium & $\operatorname{Re}$ & ICP-MS & Filtered 0.45 PES & $\mathrm{mg} / \mathrm{L}$ & 0.001 \\
\hline Rhodium & $\mathrm{Rh}$ & ICP-MS & Filtered 0.45 PES & $\mathrm{mg} / \mathrm{L}$ & 0.001 \\
\hline Ruthenium & $\mathrm{Ru}$ & ICP-MS & Filtered 0.45 PES & $\mathrm{mg} / \mathrm{L}$ & 0.001 \\
\hline Antimony & $\mathrm{Sb}$ & ICP-MS & Filtered 0.45 PES & $\mathrm{mg} / \mathrm{L}$ & 0.001 \\
\hline Scandium & Sc & ICP-MS & Filtered 0.45 PES & $\mathrm{mg} / \mathrm{L}$ & 0.05 \\
\hline Selenium & Se & ICP-MS & Filtered 0.45 PES & $\mathrm{mg} / \mathrm{L}$ & 0.05 \\
\hline Silicium & $\mathrm{Si}$ & ICP-MS & Filtered 0.45 PES & $\mathrm{mg} / \mathrm{L}$ & 5 \\
\hline Samarium & $\mathrm{Sm}$ & ICP-MS & Filtered 0.45 PES & $\mathrm{mg} / \mathrm{L}$ & 0.001 \\
\hline Tin & Sn & ICP-MS & Filtered 0.45 PES & $\mathrm{mg} / \mathrm{L}$ & 0.001 \\
\hline Strontium & $\mathrm{Sr}$ & ICP-MS & Filtered 0.45 PES & $\mathrm{mg} / \mathrm{L}$ & 0.005 \\
\hline Tantalum & $\mathrm{Ta}$ & ICP-MS & Filtered 0.45 PES & $\mathrm{mg} / \mathrm{L}$ & 0.001 \\
\hline Terbium & $\mathrm{Tb}$ & ICP-MS & Filtered 0.45 PES & $\mathrm{mg} / \mathrm{L}$ & 0.001 \\
\hline Tellurium & $\mathrm{Te}$ & ICP-MS & Filtered 0.45 PES & $\mathrm{mg} / \mathrm{L}$ & 0.001 \\
\hline Thorium & Th & ICP-MS & Filtered 0.45 PES & $\mathrm{mg} / \mathrm{L}$ & 0.001 \\
\hline Titanium & $\mathrm{Ti}$ & ICP-MS & Filtered 0.45 PES & $\mathrm{mg} / \mathrm{L}$ & 0.005 \\
\hline Thallium & $\mathrm{Tl}$ & ICP-MS & Filtered 0.45 PES & $\mathrm{mg} / \mathrm{L}$ & 0.005 \\
\hline Thulium & $\mathrm{Tm}$ & ICP-MS & Filtered 0.45 PES & $\mathrm{mg} / \mathrm{L}$ & 0.001 \\
\hline Uranium & $\mathrm{U}$ & ICP-MS & Filtered 0.45 PES & $\mathrm{mg} / \mathrm{L}$ & 0.001 \\
\hline Vanadium & $\mathrm{V}$ & ICP-MS & Filtered 0.45 PES & $\mathrm{mg} / \mathrm{L}$ & 0.005 \\
\hline Tungsten & $\mathrm{W}$ & ICP-MS & Filtered 0.45 PES & $\mathrm{mg} / \mathrm{L}$ & 0.001 \\
\hline Yttrium & $\mathrm{Y}$ & ICP-MS & Filtered 0.45 PES & $\mathrm{mg} / \mathrm{L}$ & 0.001 \\
\hline Ytterbium & $\mathrm{Yb}$ & ICP-MS & Filtered 0.45 PES & $\mathrm{mg} / \mathrm{L}$ & 0.001 \\
\hline Zink & $\mathrm{Zn}$ & ICP-MS & Filtered 0.45 PES & $\mathrm{mg} / \mathrm{L}$ & 0.05 \\
\hline Zircon & $\mathrm{Zr}$ & ICP-MS & Filtered 0.45 PES & $\mathrm{mg} / \mathrm{L}$ & 0.001 \\
\hline
\end{tabular}




\section{References}

1. Voutchkova, D.D.; Ernstsen, V.; Hansen, B.; Sørensen, B.L.; Zhang, C.; Kristiansen, S.M. Assessment of spatial variation in drinking water iodine and its implications for dietary intake: A new conceptual model for Denmark. Sci. Total Environ. 2014, 493, 432-444. [CrossRef] [PubMed]

2. Voutchkova, D.; Schullehner, J.; Knudsen, N.; Jørgensen, L.; Ersbøll, A.; Kristiansen, S.; Hansen, B. Exposure to Selected Geogenic Trace Elements (I, Li, and Sr) from Drinking Water in Denmark. Geosciences 2015, 5, 45-66. [CrossRef]

3. Knudsen, N.N.; Schullehner, J.; Hansen, B.; Jørgensen, L.F.; Kristiansen, S.M.; Voutchkova, D.D.; Gerds, T.A.; Andersen, P.K.; Bihrmann, K.; Grønbæk, M.; et al. Lithium in drinking water and incidence of suicide: A nationwide individual-level cohort study with 22 years of follow-up. Int. J. Environ. Res. Public Health 2017, 14, 627. [CrossRef] [PubMed]

4. Kessing, L.V.; Gerds, T.A.; Knudsen, N.N.; Jørgensen, L.F.; Kristiansen, S.M.; Voutchkova, D.; Ernstsen, V.; Schullehner, J.; Hansen, B.; Andersen, P.K.; et al. Association of lithium in drinking water with the incidence of dementia. JAMA Psychiatry 2017, 74, 1005-1010. [CrossRef] [PubMed]

5. $\quad$ Kessing, L.V.; Gerds, T.A.; Knudsen, N.N.; Jørgensen, L.F.; Kristiansen, S.M.; Voutchkova, D.; Ernstsen, V.; Schullehner, J.; Hansen, B.; Andersen, P.K.; et al. Lithium in drinking water and the incidence of bipolar disorder: A nation-wide population-based study. Bipolar Disord. 2017, 19, 563-567. [CrossRef] [PubMed]

6. Lv, S.; Wang, Y.; Xu, D.; Rutherford, S.; Chong, Z.; Du, Y.; Jia, L.; Zhao, J. Drinking water contributes to excessive iodine intake among children in Hebei, China. Eur. J. Clin. Nutr. 2013, 67, 961-965. [CrossRef] [PubMed]

7. Shen, H.; Liu, S.; Sun, D.; Zhang, S.; Su, X.; Shen, Y.; Han, H. Geographical distribution of drinking-water with high iodine level and association between high iodine level in drinking-water and goitre: A Chinese national investigation. Br. J. Nutr. 2011, 106, 243-247. [CrossRef] [PubMed]

8. Pedersen, K.M.; Laurberg, P.; Nøhr, S.; Jørgensen, A.; Andersen, S. Iodine in drinking water varies by more than 100-fold in Denmark. Importance for iodine content of infant formulas. Eur. J. Endocrinol. 1999, 140, 400-403. [CrossRef] [PubMed]

9. Andersen, S.; Petersen, S.B.; Laurberg, P. Iodine in drinking water in Denmark is bound in humic substances. Eur. J. Endocrinol. 2002, 147, 663-670. [CrossRef] [PubMed]

10. Rasmussen, L.B.; Larsen, E.H.; Ovesen, L. Iodine content in drinking water and other beverages in Denmark. Eur. J. Clin. Nutr. 2000, 54, 57-60. [CrossRef] [PubMed]

11. Voutchkova, D.D.; Ernstsen, V.; Kristiansen, S.M.; Hansen, B. Iodine in major Danish aquifers. Environ. Earth Sci. 2017, 76. [CrossRef]

12. Voutchkova, D.D.; Kristiansen, S.M.; Hansen, B.; Ernstsen, V.; Sørensen, B.L.; Esbensen, K.H. Iodine concentrations in Danish groundwater: Historical data assessment 1933-2011. Environ. Geochem. Health 2014, 36, 1151-1164. [CrossRef] [PubMed]

13. Union of European Soft Drinks Associations Sales Volume Statistics by Industry Analyst "Canadean". Available online: http:/ / www.unesda.eu/products-ingredients/consumption/ (accessed on 1 September 2014).

14. Sørensen, B.L.; Møller, R.R. Evaluation of total groundwater abstraction from public waterworks in Denmark using principal component analysis. Geol. Surv. Den. Greenl. Bull. 2013, 28, 37-40.

15. Danish Nature Agency (Naturstyrelsen). Videregående Vandbehandling; Danish Nature Agency: Copenhagen, Denmark, 2012.

16. Hansen, M.; Thomsen, C.T. An integrated public information system for geology, groundwater and drinking water in Denmark. Geol. Surv. Den. Greenl. Bull. 2017, 38, 69-72.

17. Schullehner, J.; Hansen, B. Nitrate exposure from drinking water in Denmark over the last 35 years. Environ. Res. Lett. 2014, 9, 095001. [CrossRef]

(C) 2018 by the authors. Licensee MDPI, Basel, Switzerland. This article is an open access article distributed under the terms and conditions of the Creative Commons Attribution (CC BY) license (http:// creativecommons.org/licenses/by/4.0/). 